\title{
KUFAN HADITH TRANSMITTERS AND GEOPOLITICS IN EARLY PERIOD OF ISLAM
}

Novizal Wendry, ${ }^{\star A}$ A6dul Majid, ${ }^{\star \star}$ and Susilawati ${ }^{\star \star \star ~}$

* Universitas Islam Negeri Imam Bonjol Padang, Indonesia

** Institut Agama Islam Negeri Samarinda, Indonesia

*** Marmara University, Turkey

E-mail: novizalwendry@uinib.ac.id

\section{Abstract}

This article discusses the hadith transmitters involvement in Kufa politic dynamic in the early time of Islam Period, which was experiencing a long range of social turmoils. These turmoils occurred from $40 \mathrm{H} / 661 \mathrm{AD}$ until the end of the Umayyad dynasty in $125 \mathrm{H} / 743 \mathrm{AD}$. This article adopts a historical approach to conceive of the dynamic of politics among the hadith transmitters. This research revealed that the hadith transmitters built the city of Kufa. The behavior related to discrimination toward the opponents and the disappointments on the Umayah Dynasty triggered many rebellions such as alHusayn ibn 'Alî ibn Abî Tâlib, Ibn al-Zubayr, Mukhtâr al-Thaqafî, altawwâbûn, and Zayd ibn 'Alî. These turmoils involved Sa'd ibn Abî Waqqâs and al-Mughîrah ibn Shu'bah. We argue that the hadith transmitter influenced the hadiths they narrated. Based on the investigation of the two hadith contents that they narrated indicated that they took the side of the Mu'âwiyah Dynasty and 'Alî's followers as the opponents.

Artikel ini mendiskusikan keterlibatan sejumlah periwayat hadis dalam dinamika perpolitikan di Kufah pada masa awal Islam yang menimbulkan gejolak sosial masyarakat berkepanjangan. Gejolak ini terjadi mulai dari tahun $40 \mathrm{H} / 661 \mathrm{M}$ hingga penghujung Dinasti Umayyah tahun 125 H/743 M. Tulisan ini mengadopsi pendekatan historis untuk memahami 
dinamika politik di antara para periwayat. Riset ini menemukan bahwa kota Kufah dibangun oleh sahabat yang sebagian periwayat hadis. Perlakuan diskriminasi terhadap oposisi dan kekecewaan mereka terhadap Dinasti Umayyah menimbulkan beberapa gelombang pemberontakan seperti alHusayn ibn 'Alî ibn Ab̂̂ Tâlib, Ibn al-Zubayr, Mukhtâr al-Thaqafî, altawwâbûn, dan Zayd ibn 'Alî. Gejolak ini melibatkan periwayat seperti Sa'd ibn Ab̂̂ Waqqậ dan al-Mughîrah ibn Shu'bah. Kami berargumen bahwa afiliasi periwayat politik berpengaruh terhadap hadis yang diriwayatkannya. Berdasarkan investigasi terhadap dua konten hadis yang mereka riwayatkan menunjukkan indikasi keberpihakan mereka terhadap penguasa Mu'âwiyah dan oposisi pengikut 'Alî.

Keywords: hadith transmitter; geopolitics; Kufan society

Received: October 1, 2020; Accepted: December 13, 2020

\section{Introduction}

The issue of the hadith transmitter complicity in the early Islam period becomes an interesting topic to discuss. It related to the theory that no text came free of historical context (Roibin 2018, 132; Ridho 2019). Indeed, this aspect should be related to their credibility in the attempt of narrating the hadith besides the authenticity. Meanwhile, the Sunnî school held that all Prophet's companions were credible ('adûl), they were individually reliable (Ibn 'Alî 1993). There is a need to specify the topic into a more micro case, such as what could be found in Kufa, an ideal city of Islam and became the center of economy and science development under the Umayyah Dynasty.

To this research concern, Schacht and Dickinson viewed Kufa on how the local transmitters became the main object of hadith critics, which were mainly identified as Hijazian school (Dickinson 2001; Schacht 1950). In a different view, Hind and al-Zubaydî had formulated the Kufa social stratification that consisted of Arabian aristocratics (ashrâf al-qabâ'il), slaves, former slaves (mawâlî), khawârij, and followers of 'Alî (al-Zubaydî, 1970; Hind, 1971). Jabali responded it by focusing his work to map the lay of the companions who migrated to Kufa because of Islam, hijrah, and jihâd (Jabali, 2010). In a more specific context, Nadia explains female transmitters complicity, such as 'Âishah and Asmâ' bint Abû Bakr in politic and 
contributes to the contents of the hadith she narrated (Nadia 2017). Barzegar, Hansu, Holtzman, Abu-Alabbass et al. explore socio-political dynamics related to the transmission of hadith in early Islam (Abu-Alabbas 2017; Barzegar 2015; Baugh 2017; Hansu 2016; Holtmann 2014; Holtzman 2018; Liew 2019). Ulum, in his doctoral research, proves from the other side that political alliances affect the acceptance or rejection of a hadith. He emphatically stated that the traditions that support the ruler tend to be accepted and vice versa (Ulum 2019).

Considering those researches above, there is an urgency to conduct a further track on the Kufa geopolitics and the hadith transmitters. The purpose of this research is to examine the theory that the Kufa is "the city of insurgents" there were many transmitters involved. The author reconstructs it diachronic in the form of the historicity companion's migration to Kufa and the political dynamics during the Umayyads period in Damascus. Furthermore, this article traced two hadith transmitters of Kufa; Sa'd ibn Abî Waqqâs and al-Mughîrah ibn Sa'd. This investigation was intended to prove that their alignment with the Umayyad rulers influenced the content of the hadiths they narrated.

This research is categorized as a qualitative research taking the data sources from library. The primary data was acquired from classic Islam history literature such as Kitâb al-Tabaqât al-Kabîr fì al-Kûfiyyîn by Ibn Sa'd (230/845), Kitâb Futûh al-Buldân by al-Balâdhûrî (278-279/892), Târîkh alTabarî writen by al-Tabarî (310/923), Murûj al-Dhahab written by al-Mas'ûdî (345/956), Mu'jam al-Buldân written by al-Hamawî (626/1229), and al-Kâmil fi al-Târîkh written by Ibn al-Athîr (630/1233). Data of Kufa's sociohistories was inventoried and categorized according to this theme's needs based on specific periods, then analyzed on historical explanation (Kaelan 2005; Kuntowijoyo 2008).

\section{The Kufa Historicity and Transmitters Migration}

According to Jabali, there were 335 Prophet Muhammad's companions migrated and stayed in Kufa (Jabali 2010, 331-91). In terms of hadith the companions' role is as the first listener who transmitted the messages, saw, and directly watched the prophet. They (the companions) were responsible for teaching the prophetic custom, in the new place that had been covered by Muslim troops. Kufa is located along the Eufrat river, 10 kilometers far from Najaf city. In different lini, it is laid 162 kilometers far from Bagdad and 6 kilometers from Hîrah. Kufa is also noted 16 2/3 
mile squires wide or equals to 43.17 kilometres (al-Hamawî n.d., vol. 4, 490; al-Zubaydî 1970, 36).

Before Islam, Kufa was familiar in common. It was only a small place in Babilonia, Iraq. It became more well-known after Islam came, under "Umar ibn al-Khattâb. A classic historian, al-Hamawî stated that the name "Kufa" was used after Islam control this city. He added that the "Kufa" taken from a hill name, Kûfâna recognized in Arabian poetry, ra'aytu kûfânan wa kûfâna. However, another idea also confirmed this was a place where many people got together from many places, so that people call it part (qiț'ah) of a country (al-Hamawî n.d., vol. 4, 490-91).

Kufa was mainly controlled by Islam troops in $17 / 639$ led by Sa'd ibn Abî Waqqâs (d. 55/674) (Haider 2011, 3). He was one of the prophet companions beside transmitters of the hadith as recorded in Șahîh al-Bukhârî and Sahîh Muslim. This big historical event happened after Muslim troops conquer the capital city of Sassanid in al-Madâ'in and Basra. Al-Zubaydî explains that this was inhabitant with no one lived there (al-Zubaydî 1970, 21). Ibn Khaldûn (d. 808/1406) tell that it was hard for the soldiers to deal with the geographical condition of Iraq, especially at the beginning time of the expansion and this makes Sa'd told what his soldiers complaint to 'Umar by saying "wa al-Arab lâ yuwâfiquhâa min al-bilâd illâ mâ yuwâfiqu ibluhâ" (The Arabian cannot adapt to an area where their camels cannot adapt). Then, they tried to find a more supporting place, fertile, with water supply and unextreme. They search the place along Iraq to find a strategic place to save their war tools and guns. After finding the place, they started to build houses and warehouses (al-Amîn 2002, vol. 20, 44; Ibn Khaldûn 1992, vol. 2, 524-25).

Another information explains that Sa'ad occupied al-Madâ'in as the rest area for him and the troops. The messengers report the current condition to "Umar in Medina. The significant change of their body shape wondered "Umar. The messengers replied "wa khûmat al-balad qad gayyaratnâ" (land condition has made us changed). "Umar asked them to find a more feasible place and suitable for the Arabian troops until they finally found Kufa. Kufa was the second city to be built in Iraq after Basra (al-Amîn 2002; Ibn Khaldûn 1992).

Based on the land condition, Kufa was a strategic place against all trade corners (multaqâ al-turuq), making this place the center economy activities and easier for the troops to surrounding areas. It was a gate to 
Persia, helping the troops prepare themselves if they wanted to go for the next expansion. By considering this condition, they make Kufa as the barrack of Muslim troops (qayrawân) (Jafri 2007). Considering the fertility and the friendly climate, the caliph proposed the city to be the center of the new conquered centre city of migration with the Muslim citizen. 'Umar called it as dâr al-hijrah (al-Balâdhurî n.d.). Obviously, most of the companions were the hadith transmitters moving to this city.

As the second conquered city after Basra, Kufa was regarded as the Islam model city (qubbat al-Islâm). Once upon a time, 'Umar and 'Alî wrote a letter to Kufa people, called ra's al'Arâb wa jamjamatuhâ (Ibn Sa'd 1909, vol. 6, 3), Jafri called as the genuine Islam metropolitan city (Jafri 2007). Besides, since there was still a few people who lived in this city, it was easy to control by the sovereign. A governor managed Kufa. According to alSha'bî and some other sources, some companios becoming a governor in Kufa were Abû 'Ubaydah al-Thaqafî, Sa'd ibn Abî Waqqâs, 'Ammâr ibn Yâsir, al-Mughîrah ibn Shu'bah, al-Walîd ibn 'Uqbah, Abû Mûsâ al-Ash'arî, 'Imârah ibn Shihâb, Ziyâd ibn Abîhi, al-Dahhạak ibn Qays, al-Nu'mân alBashîr, Muslim ibn 'Uqayl, 'Ubayd Allâh ibn Ziyâd, al-Hajajâj ibn Yûsuf alThaqafî, Khâlid ibn 'Abd Allâh al-Qasrî, and Yûsuf ibn 'Umar. They officiated as the authorized caliphs (al-Balâdhurî n.d., vol. 2, 343; Ibn Sa'd 1909, vol. 6; 7, 12, 15, 35, 36; al-Ṭabarî 2003, vols. 2; 3, 71, 831; al-Ṭabrânî 1983, vol. 20, 367).

\section{The Politic Turmoil in Kufa: al-Ḥusayn ibn 'Alî}

The historical background of choosing al-Husayn ibn 'Alî as the caliph was not the same as the previous caliphs. They were appointed as the support of both muhâjirîn and ansâr companions. According to Hitti, it was the first form of Islam republic in history because the leader was appointed by involving all Arabian clans (Hitti 2013, 229). On the other way, Mu'âwiyah appointed as the Damascus caliph after Siffin war agreement. Mu'âwiyah appointed his son Yazîd as the crown prince who would replace his position. He perpetuated his power by running the legacy system. This led some circles to become unsatisfied, especially the ex 'Alî's followers.

Al-Hasan, Muhammad's grandson, is one of the hadith transmitters from 'Alî's descendant. After the death of 'Alî, he was appointed to a caliph to replace his father position for five and a half month. Al-Hasan gave the authority to Mu'âwiyah in 41/661 because of being apprehensive with the 
current Islam condition who experienced discord (Hitti 2013, 236; Ibn alAthîr 2006, 3). He appointed Mu'âwiyah as like people in Suriah appointed Mu'âwiyah. Historically, this moment was recorded as the year of unity recovery-'âm al-ijtimâ' (Sou'yb 1977, 15). Those who followed al-Hasan refuse to choose Mu'âwiyah even later they agreed. Al-Husayn, his brother, was one of those who disagreed. He proposed a protest since he thought that al-Hasan forgot their father murder incident. Al-Hasan convinced his brother and thought that he understood more about Mu'âwiyah (Ibn alAthîr 2006, 5-6).

Al-Hasan passed away in 49/669 after being poisoned by one of his wife, Ja'dah bint al-Ash'ath ibn Qays al-Kindî on the Mu'âwiyah demand (alMas'ûdî, 2005, vol. 2, 6). The assassination attempt was done in several time, because $\mathrm{Mu}$ 'âwiyah had been worrying if the throne turned back to the shûra council. As quoted by Hashem from Ibn Hajar that one of the

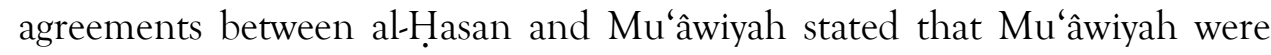
not allowed appointed his son as the caliph, but the election must be authorized by shûra council which examined the conventional way in Khalifah râshidûn era (Hashem 1989, 52).

The 'Alî followers expected would be appointed and replaced his brother as the caliph as Mu'âwiyah had promised. On the other side, Mu'âwiyah thought that it is important to a figure of the next caliph. This change would trigger a struggle for power if he did not intervene the election. This remained him to the turmoil after 'Alî killed. To respond this case, he proposed his son, Yazîd, to be the caliph. His son's appointment as the crown prince was run as the new tradition in the Islam leadership and never been practiced in the prophet and râshidûn caliph period. A letter written by Mu'âwiyah in 55 , noticed that Mu'âwiyah want to do polling about the next caliph candidate through Marwân ibn al-Hakam (Ibn alAthîr, 2006, vol. 3, 99-100; Nashiruddin and Suwirta 2020).

The Sham people, as the basis of Mu'âwiyah, approved the appointment. However, the main leaders such as Ibn Abî Bakr tried to reproach the Mu'âwiyah decision in proposing his son in his response to Marwân ibn al-Hakam suggestion and accusing Mu'âwiyah of being liars who continued the Heracles tradition, Heraclius used to be replaced by the next Hareclius. The same rejection was also addressed by 'Âishah, al-Husayn ibn 'Alî, Ibn al-Zubayr, 'Abd Allâh ibn 'Umar, and 'Abd al-Raḥmân ibn Abî Bakr who did not agree to this appointment (Ibn al-Athîr 2006, vol. 3, 100; Samarjani and Nia 2015). 
Before his death, Mu'âwiyah remind Yazîd for being careful of the three leaders; al-Husayn, Ibn al-Zubayr and Ibn 'Umar (Ibn al-Athîr 2006, vol. 3, 120, 127; Hagler 2013; Buana 2020). This worry was reasonable because he had been knowing much about them, and they hardly refuse for Yazîd appointment to be the crown prince. Yazîd was named the successor of the Mu'âwiyah caliph in Rajab in $60 \mathrm{AH}$. As predicted by Mu'âwiyah, the people of Hijaz rejected Yazîd. The force behind this rejection were three main figures, as mentioned by Mu'âwiyah. The rejection also came from the Iraq people. They pledged allegiance to al-Husayn or Ibn al-Zubayr more than Yazîd in Damascus (al-Ṭabarî 2003, vol. 3, 1012; Ikhsan 2013; Kasdi 2015).

After listening to the rejection, Yazîd sent the troops under al-Walîd ibn 'Utbah to make the Hijaz leaders willing to pledge allegiance. Ibn 'Umar submitted to the messenger of Yazîd and was willing to pledge allegiance if others also pledged allegiance (al-Ṭabarî 2003, vol. 3, 1010; Ibn al-Athîr 2006, vol. 4, 14, 17). Al-Husayn and Ibn al-Zubayr considered to reject it and moved to Mecca. This attitude was followed by Mecca citizens who stand behind al-Husayn and Ibn al-Zubayr reject to allegiance Yazîd.

'Abd Allâh ibn Mutîi' met al-Husayn and express his loyalty. He asked for the futher steps. Al-Husayn answered, "I am going to go to Mecca now, after that I want to do istikhârah". Ibn Muṭ̂‘ remind al-Husayn going Mecca is almost similarly arrived in Kufa. He added the Kufan are guiles, the place where his father 'Alî was killed (Ibn al-Athîr 2006, vol. 3, 132). At the same time Sulaymân ibn Șurad, one of the Kufan leaders, such as Rifâ'ah ibn Shaddâd to Habîb ibn Mutahhir to discuss the Kufan desire to pledge of allegiance al-Husayn since they feel reluctant to Yazîd. They agreed to invite al-Husayn come to Kufa by sending a letter to through 'Abd Allâh ibn Sab' al-Hamdânî. Two days later, the Kufans sent two messengers with 150 letters to support al-Husayn to join them in Kufa.

Al-Husayn replied to the letter through his cousin Muslim ibn 'Uqayl. He read the al-Husayn letter to the people of Kufa:

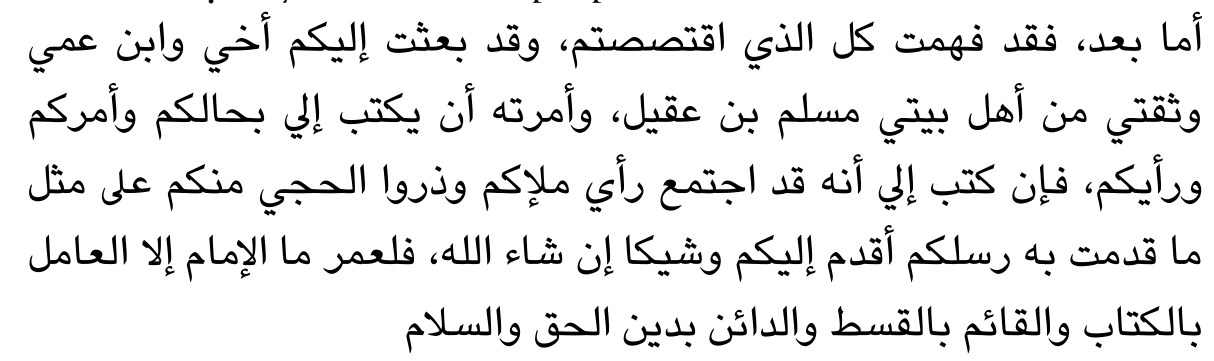


"I really understand what you are telling me. For this reason, I sent my cousin Musim ibn 'Uqayl and I ordered him to monitor your conditions and desires. It has also arrived (news) to me about the condition of your area (Kufa) as conveyed by your delegation, therefore, I sent a messenger to you, for the sake of Allah will give a fair witness and carry out the duties properly, respectfully" (Ibn al-Athîr, 2006, vol. $3,133)$.

There were many of Kufan concerned and be full of hope when they know the letter message. The Muslim people had success to gather twelve thousand people of Kufa and declared their support for al-Husayn to be the caliph as Mu'âwiyah successor (al-Tabarî 2003, vol. 3, 1010). Meanwhile, the Umayyah authority for Iraq, Nu'mân ibn Bashîr could not handle the situation. According to al-Ṭabarî, Nu'mân partisans prefer obeying to disobedience toward Allah command. Nu'mân then delivered to Yazîd and it caused a fire. Yazîd appointed 'Ubayd Allâh ibn Ziyâd as the lord of Kufa who were in charge as Basra's governor. 'Ubayd Allâh used a strategic way to handle the turmoils of Kufa who pledged al-Husayn by killing Muslim ibn 'Uqayl, the emissary of al-Husayn (al-Tabarî 2003, vol. 3, 1011).

In Mecca, al-Husayn heard the news about the Kufa pledge of allegiance from a messenger, Muslim ibn 'Uqayl. It drove him to go to Kufa. Some companions tried to stop him; Ibn 'Abbâs, Ibn 'Umar, and Ibn alZubayr warned him that it was only guile and told him what happened to 'Alî, his father. Even Ibn al-Zubayr declared his loyalty if al-Husayn were willing to be the caliph and persuaded people in Hijaz to have the pledge of allegiance on him (Sou'yb 1977, 55-56; al-Tabarî 2003, vol. 3, 1025). This advice could not cancel his desire going to Kufa. Finally, al-Husayn and his group decided to join the Kufan.

On the other side, 'Ubayd Allâh ibn Ziyâd seat 2000 armies under alHurr ibn Yazîd al-Tamîmî command. Al-Husayn knew his entourage is in danger. After doing a negotiation, he suggested his man who wanted to go back to Mecca to immediately arrive in Mecca (al-Ṭabarî 2003, vol. 3, 1031). On the other side, al-Husayn believed that his travel to Kufa was for a peaceful mision and not for war. Al-Husayn and his group were stopped by 'Ubayd Allâh under al-Hurr ibn Yazîd al-Tamîmî. He thought that Yazîd wanted to deceive by carrying a small number of troops with more troops behind. Al-Husayn hoped can influence al-Hurr to support him without 
realizing that Iraq forces were in a difficult condition. They are under the 'Ubayd Allâh ibn Ziyâd clutches, but they still acknowledged al-Husayn pledge of allegiance (al-Ṭabarî 2003, vol. 3, 1026).

Both al-Husayn and al-Hurr did meet compromise, and al-Husayn was required to go back to Medina. 'Ubayd Allâh ibn Ziyâd instructed al-Hurr pressing al-Husayn to move to a dry land called Karbala. In his own prediction, al-Husayn brought 4000 additional armies from Mecca. At that time, al-Husayn could recognize his position and offered three options; provided an opportunity to safely return to Hijaz, provide an opportunity to meet Yazîd in Damascus, or draw a line of defense in an equal way. Due to the rejection, al-Husayn was murdered in Karbala (Kroes 2016; al-Tabarî 2003, vol. 3, 1027). All of the group members were also killed, except women and children. Al-Husayn head was beheaded and taken along with women and children, 'Alî Zayn al-'Âbidîn to Governor Ibn Ziyâd in Damascus.

\section{The Rebellion of 'Abd Allâh ibn al-Zubayr}

'Abd Allâh ibn al-Zubayr is the son of al-Zubayr ibn al-Awwâm, a prophet companion. He is an 'Alî follower who died in Șiffîn war. He had a close relation with the Hijaz people. His mother is Asmâ' bint Abî Bakr, the 'Âishah brother in law. His grandmother-Zubayr ibn al-'Awwâm's motheris Șafiya bint 'Abd al-Muttalib, the prophet's aunt. He was one of the Hijaz leaders from the prophet's companions has strong authority in rejecting the Yazîd pledge of allegiance as the caliph (the successor of his father). Ibn alZubayr was one of those who prevent al-Husayn ibn 'Alî to go to Kufa, which were ended by al-Husayn death in Karbala. He was the first baby born at the first year of Hijrah (al-Dhahabî 2001, vol. 3, 363-64; al-Bukhârî n.d., vol. 1, 9).

Ibn al-Zubayr lived for five generations in the period of Umayyah (Mu'âwiyah, Yazîd, Mu'âwiyah II, Marwân ibn al-Ḥakam and 'Abd al-Mâlik ibn Marwân). He did not take an oath of allegiance to the last four caliphs. Indeed, after al-Husayn was killed, he announced himself as the caliph. The death of al-Husayn and his troops had triggered the Hijaz people anger. Ibn al-Zubayr used this opportunity and caused the revocation of the oath of allegiance to the people of Hijaz toward Yazîd (al-Tabarî 2003, vol. 3, 1060; Ilhan 2018). He proclaimed himself the caliph and got the oath of allegiance from the Hijaz people and followed by the Yemeni and the South Arabian. 
The Hijaz Ummayah governor, Marwân ibn al-Hakam, who would later become the Umayyad caliph, could not contain the atmosphere in the Hijaz. Marwân ibn al-Hakam, later become the Umayyad caliph, could not contain the Hijaz situation. With his successor 'Uthmân ibn Muhammad, he left Mecca (al-Ṭabarî 2003, vol. 3, 1063). Yazîd, the caliph, heard this news and sent 'Utbah, the moslem commander to handle the situation in Hijaz. The 'Utbah troops (64 H/685 AD) was intercepted by 'Abd Allâh ibn Hanzalah, Amîr Medina version of Ibn al-Zubayr until a battle broke out. 'Abd Allâh ibn Hanzalah could be defeated. On the way to Mecca, Muslim ibn 'Utbah passed away and replaced by his vice al-Huṣayn ibn alNamîr. Ibn al-Namîr was successfully press Ibn al-Zubayr and besiedge around the Ka'ba $(60 \mathrm{H})$. Ibn al-Zubayr's armies used the hills between Safa to Marwa as a fort. The defend system created Ibn al-Zubayr was very strong and could withstand Ibn al-Namîr for not entering Mecca for 40 days. Ka'ba was the becoming the target of Ibn al-Namîr armies, causing the walls in the north and southeast along with the roof to fall a part. At the same time, the cloth cover of Ka'ba was burned (Ibn al-Athîr 2006, vol. 3, 1064, 1069, 1070; al-Ṭabarî, 2003, vol. 3, 2003).

The Attack on Ibn al-Zubayr in Mecca was the first military aggression by Bani Umayyah. The failed attack, done by Ibn al-Namîr in conquering Mecca and the death of Yazîd in Damascus happened at the same time (64 $\mathrm{H} / 683 \mathrm{M})$. Ibn al-Zubayr knew about the death caliph earlier than Ibn alNamîr and his armies. He shouted that the caliph has passed away to make Ibn al-Namîr stop his attack. He told Ibn al-Zubayr to follow him going to Damascus in a whisper. Promising that he would get the oath of allegiance on Ibn al-Zubayr as the caliph, but Ibn al-Zubayr attempted a rejection and divulged the offer. Ibn al-Namîr's armies went back to Damascus, and Ibn al-Zubayr made some renovation on the Ka'ba (Ibn al-Athîr 2006, vol. 4, 207). The rejection of the oath of allegiance toward Yazîd was continued with his rejection of his son Mu'âwiyah ibn Yazîd who run the reign for three months. When Mu'âwiyah ibn Yazîd been oathed by the people of Sham in $64 \mathrm{H}$, Zubayr then been oathed the people of Hijaz. The Mu'âwiyah ibn Yazîd successor, Marwân ibn al-Hakam was busy of the Kufan complain on the al-Husayn death in $65 \mathrm{H}$. The Umayyah intention in defeating Ibn al-Zubayr was realized when 'Abd al-Mâlik was becoming the caliph of Umayyah.

'Abd al-Mâlik knew how Ibn al-Zubayr forces the pilgrims visit Mecca every year (started from $64-72 \mathrm{H}$ ) to pledge of allegiance him as the caliph. 
He planned a strategy to subdue Ibn al-Zubayr by empowering his position in Sham and Egypt. In $71 \mathrm{H} / 691 \mathrm{AD}$, 'Abd al-Mâlik succeeded in conquering Iraq and entered Kufa, and conquered Basra and appointed Khâlid ibn 'Abd Allâh as his vice. Ibn al-Zubayr brother, Maṣhab ibn alZubayr was killed in the battle. While Muhallib ibn Abî Safra, Governor of Ibn Zubayr of the Khurasan region, conquered and counter-linked 'Abd alMâlik. 'Abd al-Mâlik appointed his brother, 'Abd al-Azîz ibn Marwân become the Governor of Egypt and Bashîr ibn Marwân as Governor of Basra (Ibn al-Athîr 2006, vol. 4, 93).

The next step performed by 'Abd al-Mâlik was forbidding people pilgrimage to Mecca. He built the shrine, the Ismâ'îl shrine, qubbat al Sakhrah, in Jerusalem as a place to worship or pilgrimage to replace the pilgrimage to Mecca. The year after $(72 \mathrm{AH})$, he ordered his commander alHajjâj ibn Yûsuf who was well known for his iron fist to take the Hijaz. The battle between al-Hajjâj and Ibn al-Zubayr lasted for six months and seventeen days. Others said it lasted eight months and seventeen days. Ibn al-Zubayr was pushed back and surrounded in the grand mosque courtyard (al-Ṭabarî 2003, vol. 3, 1189-90).

Before his army was defeated, Ibn al-Zubayr met his mother Asmâ' bint Abî Bakr, she was old and blind. He asked for her advice, to surrender or to fight to the last drop of blood. Asmâ' advised him:

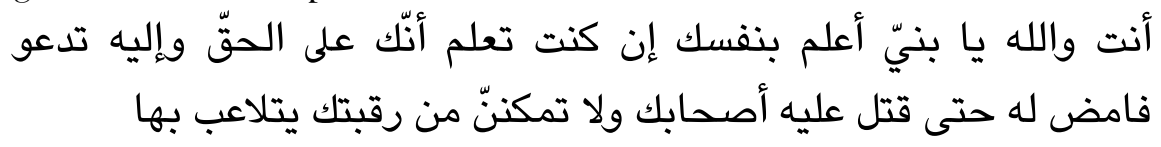

"For the sake of Allah, O my son, You know better that You are on the right path and call for it so that your followers will be killed, so that the Umayyads will not play with you" (al-Ṭabarî 2003, vol. 3, 1189-90).

Asmâ' also reminded how al-Zubayr ibn al-'Awwâm, his father, surrounded the Babylonian fort for months, and he was the first to climb the fort until the Muslim armies could enter and capture Egypt. Ibn al-Zubayr finally returned to his armies and died with his head decapitated by al-Hajjâj (73 H/693 AD).

The success gained by Ibn al-Zubayr persisted as an opposed caliph in Mecca in the five periods of the Umayyad Caliphate was causally related with khawarij, incidentally originated from Kufa. In facing Yazîd armies in 
Medina and Mecca, the khawarij was brave as troop (Wellhausen 1958, 75). Later, Ibn al-Zubayr appointed al-Muhallab ibn Abî Șafrah as the Governor of Khurasan. He placed Muṣhab ibn al-Zubayr (his brother) as governor of Kufa until 71/691.

\section{The Tawwâbûn Rebellion}

Tawwâbûn was the incooperation of those who were highly loyal to 'Alî ibn Abî Tâlib lived in Kufa and had a solidarity action on the killing of al-Husayn in the event of Karbala. They argued that most of Kufan were naive, the tribes leaders, invited al-Husayn to Kufa to be appointed as guardians or caliphs, but when al-Husayn and his entourage were ambushed and massacred in Karbala, none of them helped. For this reason, they feel guilty and want to repent by making sacrifices to break their mistakes by naming tawwâbûn, people who repent (al-Ṭabarî, 2003, vol. 2, 189).

The tawwâbûn movement began by organizing one hundred al-Husayn followers. Most of the members are above sixty years old. The movement was led by Sulaymân ibn Surâd al-Khuzza'î, the prophet companion. Ibn Surâd was supported by four tribe leaders, Fuazah, al-Uzd, Bakr and Bajilah. Based on Wellhausen's notes, none of these four leaders were originally a Yemenis. Their effort was to hold a routine recitation on Friday at Ibn Surâd's house and listen to their doctrine in surah al-Baqarah verse 54 (alTabarî 2003, vol. 2, 189).

This ayat was used as the foundation of their struggle by acknowledging the existed tyranny, namely inviting al-Husayn and leaving it in Karbala, then repenting at the expense of themselves. This action was firstly carried out clandestinely until the death of Yazîd ibn Mu'âwiyah. When Yazîd passed away, many Umayyad subordinate areas broke free because the successor Mu'âwiyah ibn Yazîd was too young and weak. This opportunity was taken by 'Abd Allâh ibn al-Zubayr by invading Iraq and sending 'Abd Allâh ibn Yazîd al-Anșârî as guardian to Kufa.

The tawwâbun warriors realized this condition, the Kufa residents and the leaders did not fully pledge 'Abd Allâh ibn al-Zubayr. The hearts of Kufa were partly still loyal to 'Alî, descendants, and they realized that 'Abd Allâh ibn al-Zubayr had stolen Alî's inheritance by proclaiming himself as the Caliph of Hijaz. 'Ubayd Allâh ibn 'Abd Allâh al-Murrî was succeeded in raising the Kufan feeling of enthusiasm to avenge the death of al-Husayn through his sermon. As a result, the number of tawwâbûns had increased to 16.000. Sympathizers' also came from al-Madâ'in and Basra. However, they 
had not been on a mission in determining how the sacrifice be made. Some of them this must be accomplished by expelling ashrâf al-qabâ'il from Kufa. Others suggested that hedirectly demand retribution from Umayyah, especially 'Ubayd Allâh ibn Ziyâd who was then the Umayyad Governor in Kufa. Tawwâbûn carried out a rebellion executed by Rabî‘ al-Thânî $65 \mathrm{H}$ a place near the city of Kufa. Surprisingly, there were only 4000 persons present among 16.000 (al-Ṭabarî 2003, vol. 2, 191, 194).

According to Wellhausen, the 4000 were Arabian ethnic from various tribes and most of the were hâfizs (memorizers of the Koran/qurrâ'), no one of them from the mawâlî. They continued their journey to Karbala, lamenting and acknowledging their mistakes at al-Husayn's grave. This group continued their trip along the Euphrates, until the Sham armies finally destroyed them. Some of them still managed to escape and put deep regret over the mistakes they had made (al-Tabarî 2003, vol. 2, 195).

\section{Mukhtâr al-Thaqafî's Rebellion}

One of the maneuvers against the Umayyah rule in Damascus was running a movement done by Mukhtâr al-Thaqafî, a figure who claimed to be the founder of the subsect of the Shî'a Râfidah. According to Ibn alAthîr, he was once detained by 'Ubayd Allâh ibn Ziyâd while arresting and killing Muslim ibn 'Uqayl in Kufa. He was accused of conspiring with Muslims ibn 'Uqayl, the messenger of al-Husayn to Kufa people. Then 'Abd Allâh ibn 'Umar-his wife was Șafiyah bint Abî 'Ubayd, Mukhtâr's sistersent a letter to Yazîd to free Mukhtâr (Ibn al-Athîr 2006, vol. 4, 169; alTabarî 2003, vol. 3, 1097-98). Mukhtâr was released and went to Hijaz to join with 'Abd Allâh ibn al-Zubayr rejecting Yazîd allegiance as the caliph. The event Ibn 'Uqayl killing was the beginning of Mukhtâr's hatred toward Yazîd.

Mukhtâr used the event of the al-Husayn killing to carry out his political efforts. At the beginning, he formed a coalition with Ibn al-Zubayr and took his part in defending the Hijaz from the Yazîd army invasion, which was led by al-Huṣayn ibn Numayr. According to Ibn al-Athîr, Mukhtâr showed his skill in fighting and could kill several soldiers. Because he had a dispute with 'Abd Allâh ibn al-Zubayr, Mukhtâr decided to go to Kufa and gained the sympathy of tribes leaders by utilizing the fanaticism of the Kufan towards the descendants of 'Alî. On the way to Kufa, he stopped at the Sakun mosque and greeted the surrounding population by saying, 
"أبشروا بالنصرة والفلج أتاكم ما تحبون" (give happy news with help and victory, you have come to your desired people) (Ibn al-Athîr 2006, vol. 4, 171). Those were the ways Mukhtâr took the fanatism sympathy of the population to the family of 'Alî. Among the tribe leaders involved were 'Ubaydah ibn 'Amr alBadawî (Bada Tribe) and Ismâ'îl ibn Kathîr (from the Hindun tribe). During a meeting, Mukhtâr preached:

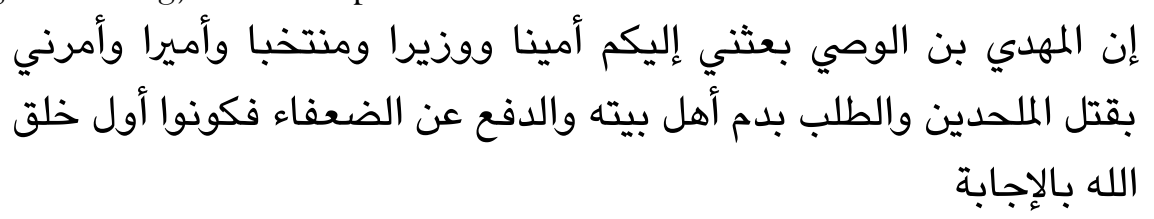

"Verily, al-Mahdî ibn al-Waṣî has sent me to you as a trusted person, wazîr, elected, and 'amîr ordered me to kill atheists and demand the blood of the ahl bayt, to defend the weak. Be all of you first creatures of Allah to accept this appeal!" (Ibn al-Athîr 2006, vol. 4, 172)

All those present pledges of allegiance, Mukhtâr and demand the death of al-Husayn. Mukhtâr's confession was attributed to Muhammad ibn 'Alî al-Hanafiyah, al-Husayn's brother and 'Alî's son from his wife from Hanafiyah tribe. Subsequently, Mukhtâr made Kufa the center of his movement. At the same time, Kufa was under the caliph 'Abd Allâh ibn alZubayr, with the center of his government in Mecca. Mukhtâr al-Thaqafî succeeded in occupying Kufa in 66/686. Mukhtâr captured and beheaded the perpetrators of the killings of al-Husayn, Șammâr ibn Ziljaushan and 'Umar ibn Sa'd. These two heads were sent to Muhammad ibn 'Alî alHanafiyah. Thus, at the same time, three camps claimed to be political leaders: the Umayyad camp with a defense base in Damascus, the Ibn alZubayr stronghold by taking Mecca as a defense base, and the Mukhtâr alThaqafî camp by occupying Kufa as its power base.

\section{The Rebellion of Zayd ibn 'Alî}

Zayd ibn 'Alî is the grandson of al-Husayn ibn 'Alî ibn Abî Tâlib from his son named 'Alî ibn al-Husayn, Imâm Sajjâd. His mother was an umm alwalad, a free servant. Shî‘ Zaydiyah considered him an imam so the name of the sect was attributed to his name. He has a good relationship with Abû Haniffah, the fourth Imam in Fiqh (law of Islam). Abû Hanîfah had ever 
given moral support to Zayd ibn 'Alî related with his plans for aggression against the Hishâm ibn 'Abd al-Mâlik government. Similar support was also given by Abû Haniffah to Zayd's followers after he was killed by the Hishâm army (Ja'fariyan 2004, 819).

This rebellion occurred in Safar $122 \mathrm{H}$. It was triggered by the accumulation of disappointments over the discriminations of Umayyad Caliphs (Hishâm ibn 'Abd al-Mâlik) and the Governor of Kufa (Khâlid ibn 'Abd Allâh Qasrî) against 'Alî descendants after Karbala. The hatred in the form of a curse was conveyed to the public on Friday Khutbah throughout the Umayyad territories. It was instilled sustainably way and well structured from royal officials to civil society. Zayd's relationship with the Caliph Hishâm ibn 'Abd al-Mâlik began to heat up when he saw Hishâm did not rebuke the Christian who insulted the Prophet. On another occasion, the Caliph Hishâm once insulted Zayd by saying that he had no right to become a caliph because he came from a descendant of slaves (Ja'fariyan 2004, 758).

Zayd's arrival in Kufa from Medina was welcomed with joy by Kufan because it was hoped to free the Kufa population, which consisted mainly of former slaves (mawâlî) and Shi'ite Muslim followers. They consider Zayd able to lead troops to destroy Damascus troops in Kufa. They see that the power of Hishâm in Kufa is small and will not be able to face 100.000 Kufa residents. Especially when Hishâm replaced governor Khâlid ibn Qisrâ with Yûsuf ibn 'Umar. Zayd did not stay in one house while in Kufa, but moved from one house to another for security reasons. The existence of Zayd is also at the invitation of the Kufa community. Meanwhile, Yûsuf ibn 'Umar, who was the Governor at that time, did not believe that Zayd was in Kufa because he understood the character of Zayd, who did not want to be involved in political matters. Zayd stayed long in the house of Naṣr ibn Khuzaymah, an influential person at Kufa at the time. Finally, Zayd lived in the house of the Azd woman, whom he married and had three children (Ibn al-Athîr 2006, vol. 5, 492). Zayd said:

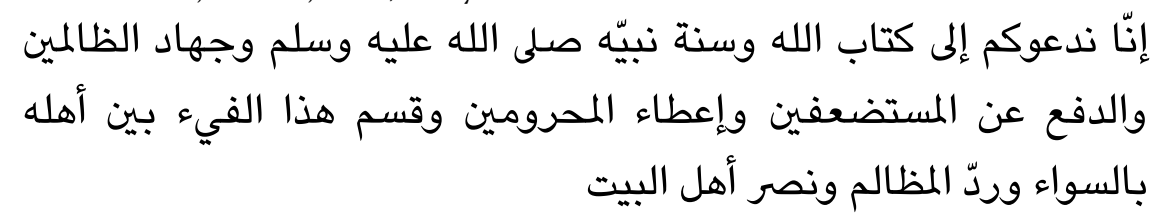

"Truthfully, we invite you to return to the Book of Allah and the Sunnah of the Prophet (saw), fight the wrongdoers, defend the 
weak, restore the rights of mahrumin, distribute al-fay' to those entitled to receive it equally, reject the wrongdoers, and help the ahl al-bayt" (Ibn al-Athîr 2006, vol. 5, 233).

The above speech has at least five points beside the reasons for Zayd's rebellion against the Kufa government, and the government has left the main teachings of Islam carried out from generation the generation after, considered to have been injustice by discriminating against non-Arabian, in this case, the mawâli and slaves who were being the majority population in Kufa, did not equally divided the booty, especially for ordinary people, peasants (ahl al-Sawâd), and discrimination toward the minority Shî‘a.

Zayd was succeeded in getting the allegiance from 15.000 Kufan, Basra and Mûșal for ten months (Wellhausen 1958, 325). Abû Ḥanîfah, Kufa hadith transmitters, provided moral support to Zayd with the influence he had and donated some money to his troops. Zayd's plan was finally heard by Yûsuf, governor of Kufa. He paid intruders into Shî‘a Muslims and claimed to be followers of Shî́a in Khurasan (Ja'fariyan 2004, 763, 766). By the caliph Hishâm command, Yûsuf gathered Kufa's people in the Jamik Mosque on Tuesday, where Zayd planned the uprising on the evening. He forced all of Kufan, without exception under the threat of being killed. Then they were interrogated and forced to divulge the information about Zayd's whereabouts and they were asked to acknowledge the plot of the revolt against Umayyah.

Followed by 218 armies, Zayd came to the Jamik Mosque on Tuesday night 1 Safar $122 \mathrm{H}$ or January 6, $740 \mathrm{AD}$, release to free up his followers. They surrounded the Kufa Mosque, but Yûsuf's armies safeguarded the mosque with arrows. One by one, Zayd's troops fell, and he was hit by an arrow on his left forehead. Zayd regained consciousness and said to the people of Kufa, "They treat me like they treat al-Husayn." At the same time, Hishâm sent 2.000 troops from Hirah, located 6 kilometers from Kufa (Ja'fariyan 2004, 768). He was rescued from the battlefield, but he died after the arrow was lifted (122 AH) (al-Bukhârî n.d., vol. 3, 403; al-Rub'î 1410, vol. 1, 285). Yûsuf successfully recognized the place Zayd stayed. His body was crucified at Kufa, while his head was sent to Sham and displayed at the Damascus gate, then sent to Medina, crucified, until Hishâm died. Yahyâ, fled to Khurasan when his son still was a child. He lived in Balkh, and was killed in $125 \mathrm{AH}$ at the time Walîd ibn Yazîd in an attack on the remnants of Zayd's followers. 


\section{The Involvement of Hadith Transmitters in Kufa Social Turmoils}

Hadith transmitters from the companion generation, tâbi'în, to atbât al-tâbi'în were involved in the sociopolitical activities of Kufa. Sa'd ibn Abî Waqqâs as one example, a prophet companion, a formidable warlord who had large authorities in leading the army to discover Kufa. His full name is Mâlik ibn Wuhayb ibn 'Abd al-Manâf ibn Zuhrah ibn Kilâb al-Zuhrî (al'Asqalânî 2003, vol. 1, 235). He was the prophet uncle to be guaranteed to go to the heaven. Sa'd was appointed as governor of Kufa, five years during the caliph 'Umar and six years during the Caliph 'Uthmân. Sa'd's involvement in the politic also indirectly affected the content of the hadith he narrated. In the hadith in Sunan al-Turmudhî it is stated:

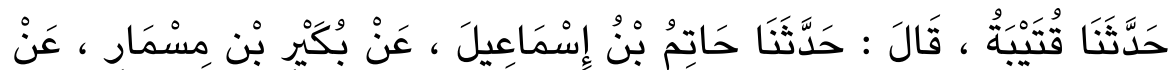

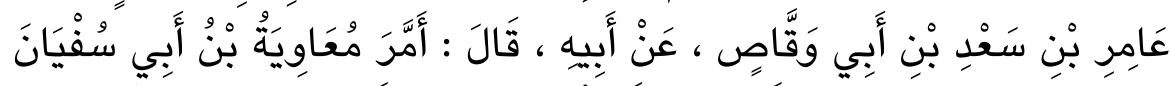

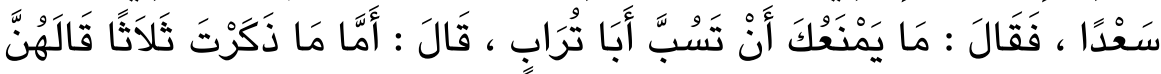

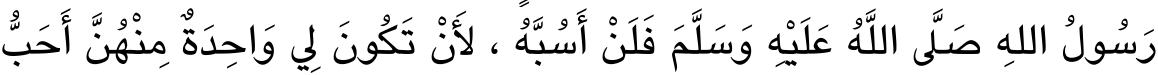

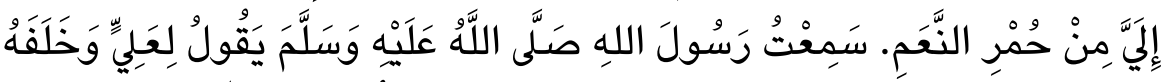

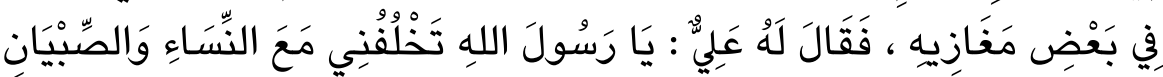

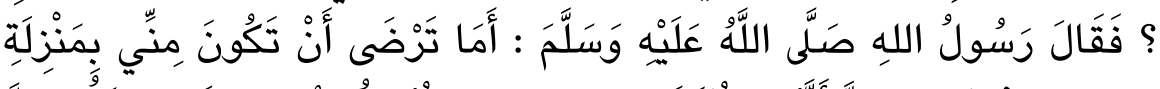

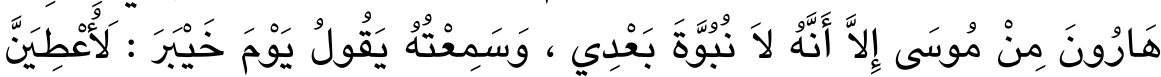

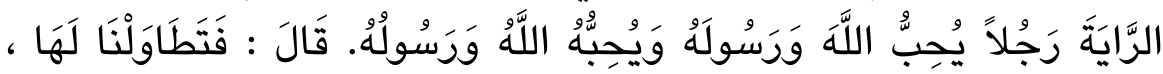

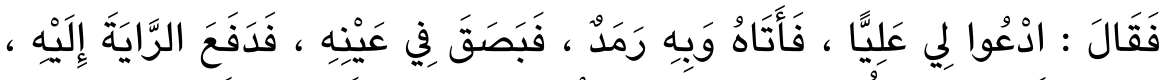

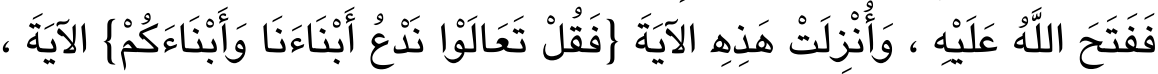

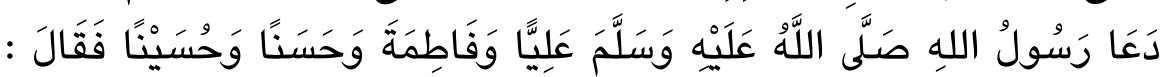

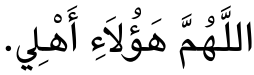

"Qutaybah told us, Hâtim ibn Ismâ'il from Bukayr ibn Mismâr from 'Âmir ibn Sa'd ibn Abî Waqqâs reported on the authority of his father that Mu'âwiyah ibn Abî Sufyân appointed Sa'd as the governor and said: What prevents you from abusing Abû Turâb ('Alî), whereupon be said: It is because of three things which I remember Allah's Messenger (may peace be upon him) having said about him that I would not abuse him and even if I find one of those three things for me, it would be more dear to me than the red camel. I 
heard Allah's Messenger (may peace be upon him) say about 'Alî as he left behind him in one of his campaigns (that was Tabuk). 'Alî said to him: Allah's Messenger, you leave me behind along with women and children. Thereupon Allah's Messenger (may peace be upon him) said to him: Aren't you satisfied with being unto me what Hâron was unto Moses but with this exception that there is no prophethood after me. And I (also) heard him say on the Day of Khaybar: I would certainly give this standard to a person who loves Allah and his Messenger and Allah and his Messenger love him too. He (the transmitter) said: We have been anxiously waiting for it, when he (the Holy Prophet) said: Call 'Alî. He was called and his eyes were inflamed. He applied saliva to his eyes and handed over the standard to him, and Allah gave him victory. (The third occasion is this) when the (following) verse was revealed: "Let us summon our children and your children." Allah's Messenger (may peace be upon him) called 'Alî, Fâtima, Hasan and Husain and said: O Allah, they are my family.” (al-Turmudhî 1998, vol. 6, no. 3724, 83)

The content of the above hadith tells about the Sa'd neutrality in facing the conflict lasted between Mu'âwiyah and 'Alî ibn Abî Tâalib. Sa'd refused to reproach 'Alî as propagated by Mu'âwiyah when he became caliph. Besides the objective point of view that the Prophet recognized 'Alî's credibility, it was likely due to familial relations, where he was the Prophet's uncle.

This case ( $\left.\mathrm{Sa}^{\prime} \mathrm{d}\right)$ was experienced by other Kufan transmitters. Ahmad ibn Hanbal told this in his Musnad that al-Mughîrah ibn Shu'bah, a companion of the prophet who had been the governor of Mu'âwiyah for four years in Kufa (al-'Asqalânî, 2003, vol. 2, 137). As a companion who is judged as a fair ('adil), he is known to have condemned 'Alî in Friday khutbah. For this attitude, he was reprimanded by other companions for the same reason, that 'Alî was one of the prophet's ten companions who was guaranteed to go to heaven and was not worthy of being cursed especially in the Friday khutbah.

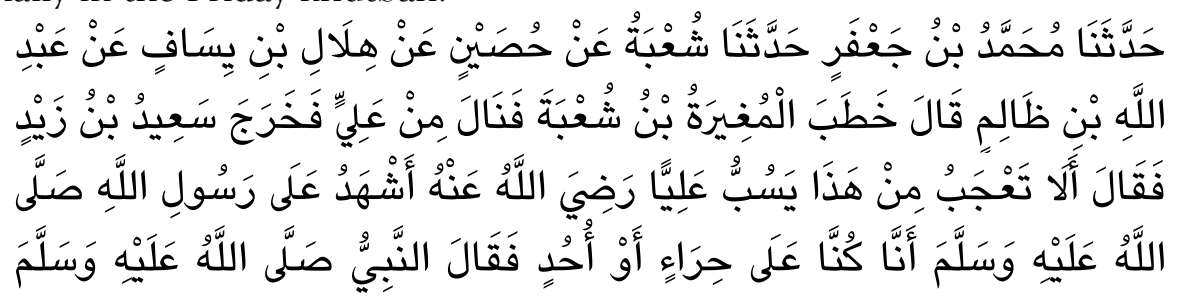




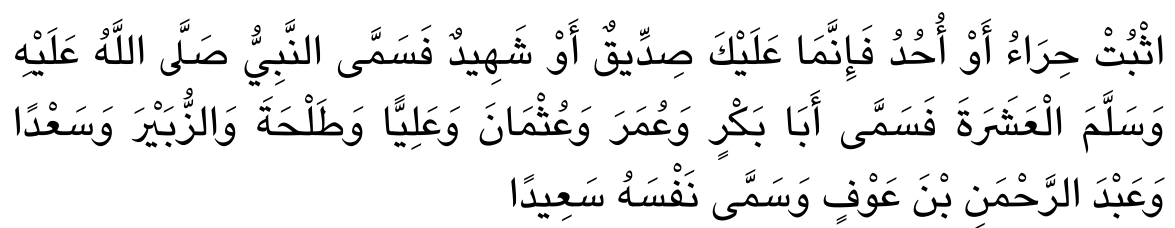

"Muhammad ibn Ja'far had told us, Shu'ba had told us, from Huṣayn from Hilâl ibn Yisâf from 'Abd Allâh ibn Zâlim said: al-Mughîrah ibn Shu'bah preached and denounced 'Alî, then Sa'id ibn Zayd stood up and said: Aren't you surprised about this person? He denounced 'Alî even though I witnessed the Prophet when we were in Hira or Uhud. The Prophet said: "Calm down O Hira' or Uhud, who is above you is a shiddiq or a martyr!" then the

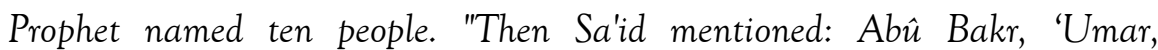
'Uthmân, 'Alî, Talha, Zubayr, Sa'd, 'Abd al-Rahmân ibn 'Awf, and he mentioned himself Sa 'îd" (Ahmad ibn Hanbal, 1995, vol. 2, no. 1638, 292).

Al-Mughîrah's unneutrality was based on the involvement of the political elements to Mu'âwiyah making he was appointed as governor of Kufa. Before the incident, al-Mughîrah also had a negative note that was not revealed by critics of Sunnî hadith (M. Abou El Fadl 2004, 168). When he was the governor of Basra during the Caliphate of 'Umar ibn al-Khattab, he used to be imam of the prayers. Abû Bakrah, another companion of the Prophet, was reluctant to share with him because Abû Bakrah and a number of his stepbrothers had witnessed him with a woman who was married to engage in sexual activity, both of them were in one house, without clothes, one of the other bodies pressing and accompanied by heavy breathing. Although then the testimony of Abû Bakrah was not accepted by the session led directly by the Caliph 'Umar ibn al-Khattâb because he was unable to testify to their sexual intercourse. Al-Mughîrah's behavior ethically did not show a credible companion.

\section{Conclusion}

The political turmoil that occurred in Kufa influenced the political tendencies of certain hadiths. This can be proven in the content (matn) of the hadith he narrated. Al-Mughîrah ibn Shu'bah for example, narrated a hadith praising the ruler on the one hand and discrediting the oppositions on the other. He was the Governor of Kufa who was appointed by 
Mu'âwiyah, took part in denouncing 'Alî in the Kufa public space as in the Friday Khutbah. This finding recommends future researchers to examine the authenticity of observant hadiths suspected of having certain political tendencies.

\section{References}

Abu-Alabbas, Belal. 2017. "The Principles of Hadith Criticism in the Writings of al-Shâfi î and Muslim." Islamic Law and Society 24(4): 31135.

DOI: https://doi.org/10.1163/15685195-00244P01

Aḥmad ibn Ḥanbal. 1995. Musnad al-Imâm Aḥmad ibn Hạbal. Cairo: Dâr alHadîth.

al-Amîn, Hasan. 2002. "al-Kûfah.” In Dâ'irat al-Ma'ârif al-Islâmiyyah AlShî́iyyah, Beirut: Dâr al-Ta'âruḍ li al-Maṭbû'ât.

al-Asqalânî, Ibn Hajar. 2003. Taqrîb al-Tahdhîb. Cairo: al-Maktabat alTawfîqiyyah.

al-Balâdhurî, Aḥmad ibn Yahyyâ ibn Jâbir. Kitâb Futûh al-Buldân. Cairo: Maktabat al-Nahḍah al-Mișriyyah.

Barzegar, Abbas. 2015. “'Adhering to the Community' (Luzûm al-Jamâ'a): Continuities between Late Umayyad Political Discourse and 'ProtoSunni' Identity." Review of Middle East Studies 49(2): 140-58.

DOI: https://doi.org/10.1017/rms.2016.35

Baugh, Carolyn. 2017. "Revolting Women? Early Kharijite Women in Islamic Sources." Journal of Islamic and Muslim Studies 2(1): 36-55.

DOI: https://doi.org/10.2979/jims.2.1.03

Buana, Cahya. 2020. "Al-Akhtal's Praise for Yazid bin Mu'wiyah, the Second Caliph of the Umayyad Dynasty (680-683 AD)." Buletin AlTuras 26(2): 221-38.

DOI: https://doi.org/10.15408/bat.v26i2.14998

al-Bukhârî, Muhammad ibn Ismâ'îl ibn Ibrâhîm Abû 'Abd Allâh. Al-Târîkh al-Kabîr. Beirut: Dâr al-Fikr.

al-Dhahabî, Shams al-Dîn Abû 'Abd Allâh Muhammad ibn Aḥmad ibn 'Uthmân ibn Qâymâz ibn 'Abd Allâh al-Turkumânî al-Fâriqî al- 
Dimashqî al-Shâfi î̀. 2001. Siyâr A'lâm al-Nubalâ. Beirut: Mu'assasat alRisâlah.

Dickinson, Eerik. 2001. The Development of Early Sunnite Hadîth Criticism: The Taqdima of Ibn Ab̂̂ Hâtim Al-Râzî. Leiden and Boston: Brill.

Hagler, Aaron. 2013. "Repurposed Narratives: The Battle of Siffīn and the and the Historical Memory of the Umayyad Dynasty." Journal of Islamic and Middle Eastern Multidisciplinary Studies 3(1): 1-27.

Haider, Najam. 2011. The Origins of the Shî'a: Identity, Ritual, and Sacred Space in Eighth-Century Kûfa. Cambridge University Press.

al-Hamawî, Shihâb al-Dîn Abû Yâqût ibn 'Abd Allâh. Mu'jam al-Buldân. Beirut: Dâr Ihyâ al-Turâth al-'Arabî.

Hansu, Hüseyin. 2016. "Debates on the Authority of Hadith in Early Islamic Intellectual History: Identifying al-Shâfi ' 1 's Opponents in Jimâ' al- 'Ilm." Journal of the American Oriental Society 136(3): 515-33. DOI: https://doi.org/10.7817/jameroriesoci.136.3.0515

Hashem, O. 1989. Saqifah Awal Perselisihan Umat. Depok: YAPI.

Hitti, K. Philip. 2013. History of the Arab. Trans. Cecep Lukman Yasin and Dedi Slamet Riyadi. Jakarta: Serambi.

Holtmann, Philipp. 2014. "A Primer to the Sunni-Shia Conflict." Perspectives on Terrorism 8(1): 142-45.

Holtzman, Livnat. 2018. Anthropomorphism in Islam: The Challenge of Traditionalism (700-1350). Edinburgh University Press. https://www.jstor.org/stable/10.3366/j.ctv7n0b7q (October 20, 2020).

Ibn 'Alî, Naṣir. 1993. 'Aqîdah Ahl al-Sunnah wa al-Jamâ'ah fî al-Ṣahâbah alKirâm. Riyad: Maktabat al-Rushd.

Ibn al-Athîr, 'Izz al-Dîn Abû al-Hasan 'Alî ibn Abî Kirâm Muḥammad ibn Muhammad ibn 'Abd al-Karîm ibn 'Abd al-Wâhịid al-Shaybânî. 2006. al-Kâmil fì al-Târîkh. Beirut: Dâr al-Kitâb al-'Arabî.

Ibn Khaldûn, 'Abd al-Rahmân. 1992. Târîkh Ibn Khaldûn. Beirut: Dâr alKutub al-'Ilmiyyah. 
Ibn Sa'd, Muḥammad. 1909. Kitâb al-Tabaqât al-Kabîr fî al-Kûfiyyîn. Leiden: E.J.Brill.

Ikhsan, Muhammad. 2013. "Politik Islam: Telaah Historis Monarchisme Mu'awiyah dan Konflik yang Mengitarinya." Jurnal Al-Adl 6(2): 96109.

DOI: http://dx.doi.org/10.31332/aladl.v6i2.202

Ilhan, Mehmet. 2018. "Abd Allah Ibn Al-Zubayr and His Career as Caliph.” Rotterdam Islamic and Social Sciences 9(1): 119-53.

Jabali, Fu'ad. 2010. Sahabat Nabi, Siapa, Ke Mana, Dan Bagaimana. Bandung: Mizan.

Ja'fariyan, Rasul. 2004. Sejarah Islam Sejak Wafat Nabi Saw. Hingga Runtuhnya Dinasti Bani Umayah (11-132 H). Jakarta: Lentera.

Jafri, S.H.M. 2007. The Origins and Early Development of Shi'a Islam. Qum: Ansariyan Publication.

Kaelan, Kaelan. 2005. Metode Penelitian Kualitatif Bidang Filsafat. Yogyakarta: Paradigma.

Kasdi, Abdurrahman. 2015. "Genealogi dan Sejarah Perkembangan Politik Islam.” Addin; Media Dialektika Ilmu Islam 9(2): 277-308.

DOI: http://dx.doi.org/10.21043/addin.v9i2.616

Kroes, Richard. 2016. “Karbala: A Battle Revisited.” Medieval Warfare 6(2): 33-38.

Kuntowijoyo. 2008. Penjelasan Sejarah (Historical Explanation). Yogyakarta: Tiara Wacana.

Liew, Han Hsien. 2019. "Ibn al-Jawzî and the Cursing of Yazîd b. Mu' âwiya: A Debate on Rebellion and Legitimate Rulership." Journal of the American Oriental Society 139(3): 631-46.

DOI: https://doi.org/10.7817/jameroriesoci.139.3.0631

Lynch, Ryan J. 2015. "Sons of the Muhâjirûn: Some Comments on Ibn AlZubayr and Legitimizing Power in Seventh- Century Islamic History." In The Long Seventh Century: Continuity and Discontinuity in an Age of Transition, eds. Alessandro Gnasso, Emanuele E. Intagliata, and Thomas J. MacMaster. Brussels: Peter Lang, 251-67. 
M. Abou El Fadl, Khaled. 2004. Atas Nama Tuhan: Dari Fikih Otoriter ke Fikih Otoritatif. Trans. Cecep Lukman Yasin. Jakarta: Serambi.

al-Mas'ûdî, Abû al-Hasan 'Alî ibn al-Ḥusayn. 2005. Murûj al-Dhahab wa Ma'âdin al-Jawhar. Beirut: Dâr al-Ma'rifah.

Nadia, Zunly. 2017. "Women Political Participation in the Era of Prophet Muhammad: Study on the Hadith Transmitters of the Women Companions." Al-Albab 6(1): 55-76.

DOI: https://doi.org/10.24260/alalbab.v6i1.608

Nashiruddin, Abdul Aziz, and Andi Suwirta. 2020. "Mu'awiyah bin Abu Sufyan: Peletak Dasar Pemerintahan Islam Monarki 661-680 M.” Factum: Jurnal Sejarah dan Pendidikan Sejarah 9(1): 75-84.

DOI: https://doi.org/10.17509/factum.v9i1.23085

Ridho, Miftahur. 2019. "Peristiwa Tahkim (Polemik Perselisihan Politik dan Implikasinya)." Humanistika: Jurnal Keislaman 5(1): 57-71.

DOI: https://doi.org/10.36835/humanistika.v5i1.147

Roibin, Roibin. 2018. "Pembacaan Kontekstual Fazlur Rahman Atas Sunah dan Hadis (Upaya Mendialektikkan Dua Tipologi Pemikiran Tradisionalis Dan Modernis).” Ulul Albab: Jurnal Studi Islam 4(2): 127 45.

DOI: https://doi.org/10.18860/ua.v4i2.6130

al-Rub'î, Muhammad ibn 'Abd Allâh ibn Aḥmad ibn Sulaymân ibn Zubur. 1410. Mawlid Al-'Ulamâ' wa Wafayâtuhum. Riyad: Dâr al-Âșimah.

Samarjani, Sadeghi, and Abbasi Nia. 2015. "Military Policies of Muaviyah in the Battle of Siffin." Journal of Applied Environmental and Biological Sciences 5(5S): 354-59.

Schacht, J. 1950. "The Origins of Muhammadan Jurisprudence." http://agris.fao.org/agris-search/search.do?recordID=XF2015046593 (April 4, 2020).

Sou'yb, Joesoef. 1977. Sejarah Daulat Umayyah I di Damaskus. Jakarta: Bulan Bintang.

al-Ṭabarî, Abû Ja'far Muhammad ibn Jarîr. 2003. Târîkh al-Ṭabarî. Beirut: Dâr Șâdir. 
al-Ṭabrânî, Sulaymân ibn Aḥmad ibn Ayyûb Abû al-Qâsim. 1983. Al-Mu'jam al-Kabîr. Mûșal: Maktabat al-Ulûm wa al-Hikam.

al-Turmudhî, Abû 'Îsâ Muhammad ibn 'Îsâ. 1998. Sunan al-Turmudhî. Beirut: Dâr al-Gharb al-Islâmî.

Ulum, Muh. Babul. 2019. Genealogi Hadis Politis al-Mu'awiyat Dalam Kajian Islam Ilmiah. Jakarta: Kemenag RI.

Wellhausen, Julius. 1958. Ahzâb al-Mu'âradah al-Siyâsiyyah al-Dîniyyah fî Ṣadr al-Islâm; al-Khawârij wa al-Shî‘ah. Cairo: Maktabat al-Nahdah alMișriyyah.

al-Zubaydî, Muhammad Ḥusayn. 1970. Al-Hayât al-ljtimâ'iyyah wa alIqtisâdiyyah fì al-Kûfah fî al-Qarn al-Awwal al-Hijrî. Cairo: al-Maṭa'at al'Âliyah. 